\title{
The Origins of the American Military Coup of 2012
}

\section{Charles J. Dunlap JR.}

This article was first published in the Winter 1992-93 issue of Parameters.

The letter that follows takes us on a darkly imagined excursion into the future. A military coup has taken place in the United States-the year is 2012-and General Thomas E. T. Brutus, Commander-in-Chief of the Unified Armed Forces of the United States, now occupies the White House as permanent Military Plenipotentiary. His position has been ratified by a national referendum, though scattered disorders still prevail and arrests for acts of sedition are underway. A senior retired officer of the Unified Armed Forces, known here simply as Prisoner 222305759, is one of those arrested, having been convicted by court-martial for opposing the coup. Prior to his execution, he is able to smuggle out of prison a letter to an old War College classmate discussing the "Origins of the American Military Coup of 2012." In it, he argues that the coup was the outgrowth of trends visible as far back as 1992. These trends were the massive diversion of military forces to civilian uses, the monolithic unification of the armed forces, and the insularity of the military community. His letter survives and is here presented verbatim.

It goes without saying (I hope) that the coup scenario above is purely a literary device intended to dramatize my concern over certain contemporary developments affecting the armed forces, and is emphatically not aprediction.

- The Author

Dear Old Friend,

It's hard to believe that 20 years have passed since we graduated from the War College! Remember the great discussions, the trips, the parties, the people?

Lieutenant Colonel Charles J. Dunlap, Jr., USAF, is the Deputy Staff Judge Advocate, US Central Command, at MacDill AFB, Florida. He is a graduate of St. Joseph's University (Pa.), the Villanova University School of Law, and the Armed Forces Staff College, and he is a Distinguished Graduate of the National War College, Class of 1992. He has taught at the Air Force Judge Advocate General's School, and served tours in Korea and the United Kingdom. In 1987 he was a Circuit Military Judge, First Judicial Circuit, and was subsequently assigned to the Air Staff in the Office of the Judge Advocates' Association as the USAF's Outstanding Career Armed Services Attorney of 1992. The present article is adapted from his National War College student paper that was co-winner of the Chairman of the Joint Chiefs of Staff 1991-92 Strategy Essay Competition, in which students from all the senior service colleges compete. 


\section{Report Documentation Page}

Form Approved

OMB No. 0704-0188

Public reporting burden for the collection of information is estimated to average 1 hour per response, including the time for reviewing instructions, searching existing data sources, gathering and maintaining the data needed, and completing and reviewing the collection of information. Send comments regarding this burden estimate or any other aspect of this collection of information,

including suggestions for reducing this burden, to Washington Headquarters Services, Directorate for Information Operations and Reports, 1215 Jefferson Davis Highway, Suite 1204, Arlington

VA 22202-4302. Respondents should be aware that notwithstanding any other provision of law, no person shall be subject to a penalty for failing to comply with a collection of information if it

does not display a currently valid OMB control number.

1. REPORT DATE

2010

2. REPORT TYPE

3. DATES COVERED

00-00-2010 to 00-00-2010

4. TITLE AND SUBTITLE

The Origins of the American Military Coup of 2012

6. $\operatorname{AUTHOR}(\mathrm{S})$

5a. CONTRACT NUMBER

5b. GRANT NUMBER

5c. PROGRAM ELEMENT NUMBER

5d. PROJECT NUMBER

5e. TASK NUMBER

5f. WORK UNIT NUMBER

7. PERFORMING ORGANIZATION NAME(S) AND ADDRESS(ES)

U.S. Army War College,Strategic Studies Institute,122 Forbes

Avenue,Carlisle,PA,17013

9. SPONSORING/MONITORING AGENCY NAME(S) AND ADDRESS(ES)

8. PERFORMING ORGANIZATION

REPORT NUMBER

10. SPONSOR/MONITOR'S ACRONYM(S)

11. SPONSOR/MONITOR'S REPORT

NUMBER(S)

12. DISTRIBUTION/AVAILABILITY STATEMENT

Approved for public release; distribution unlimited

13. SUPPLEMENTARY NOTES

14. ABSTRACT

15. SUBJECT TERMS

16. SECURITY CLASSIFICATION OF:

a. REPORT

unclassified b. ABSTRACT

unclassified c. THIS PAGE

unclassified
17. LIMITATION OF ABSTRACT

Same as

Report (SAR)
18. NUMBER 19a. NAME OF

OF PAGES

19 RESPONSIBLE PERSON 
Those were the days!!! I'm not having quite as much fun anymore. You've heard about the Sedition Trials? Yeah, I was one of those arrested-convicted of "disloyal statements," and "using contemptuous language towards officials." Disloyal? No. Contemptuous? You bet! With General Brutus in charge it’s not hard to be contemptuous.

I've got to hand it to Brutus, he's ingenious. After the President died he somehow "persuaded" the Vice President not to take the oath of office. Did we then have a President or not? A real "Constitutional Conundrum" the papers called it. ${ }^{1}$ Brutus created just enough ambiguity to convince everyone that as the senior military officer, he could - and should - declare himself Commanderin-Chief of the Unified Armed Forces. Remember what he said? "Had to fill the power vacuum.” And Brutus showed he really knew how to use power: he declared martial law, "postponed" the elections, got the Vice President to "retire," and even moved into the White House! "More efficient to work from there," he said. Remember that?

When Congress convened that last time and managed to pass the Referendum Act, I really got my hopes up. But when the Referendum approved Brutus's takeover, I knew we were in serious trouble. I caused a ruckus, you know, trying to organize a protest. Then the Security Forces picked me up. My quickie “trial” was a joke. The sentence? Well, let’s just say you won't have to save any beer for me at next year's reunion. Since it doesn't look like I'll be seeing you again, I thought I'd write everything down and try to get it to you.

I am calling my paper the "Origins of the American Military Coup of 2012.” I think it's important to get the truth recorded before they rewrite history. If we're ever going to get our freedom back, we've got to understand how we got into this mess. People need to understand that armed forces exist to support and defend government, not to be the government. Faced with intractable national problems on one hand, and an energetic and capable military on the other, it can be all too seductive to start viewing the military as a cost-effective solution. We made a terrible mistake when we allowed the armed forces to be diverted from their original purpose.

I found a box of my notes and clippings from our War College daystold my keepers I needed them to write the confession they want. It's amazing; looking through these old papers makes me realize that even back in 1992 we should have seen this coming. The seeds of this outrage were all there; we just didn't realize how they would grow. But isn't that always the way with things like this? Somebody once said that "the true watersheds in human affairs are seldom spotted amid the tumult of headlines broadcast on the hour."2 And we had a lot of headlines back in the '90s to distract us: The economy was in the dumps, crime was rising, schools were deteriorating, drug use was rampant, the environment was in trouble, and political scandals were occurring almost daily. Still, there was some good news: the end of the Cold War as well as America's recent victory over Iraq.

All of this and more contributed to the situation in which we find ourselves today: a military that controls government and one that, ironically, can't fight. It wasn't any single cause that led us to this point. Instead, it was a 
combination of several different developments, the beginnings of which were evident in 1992. Here's what I think happened:

Americans became exasperated with democracy. We were disillusioned with the apparent inability of elected government to solve the nation's dilemmas. We were looking for someone or something that could produce workable answers. The one institution of government in which the people retained faith was the military. Buoyed by the military's obvious competence in the First Gulf War, the public increasingly turned to it for solutions to the country's problems. Americans called for an acceleration of trends begun in the 1980s: tasking the military with a variety of new, non-traditional missions, and vastly escalating its commitment to formerly ancillary duties.

Though not obvious at the time, the cumulative effect of these new responsibilities was to incorporate the military into the political process to an unprecedented degree. These additional assignments also had the perverse effect of diverting focus and resources from the military's central mission of combat training and warfighting. Finally, organizational, political, and societal changes served to alter the American military's culture. Today's military is not the one we knew when we graduated from the War College.

Let me explain how I came to these conclusions. In 1992 not very many people would've thought a military coup d'état could ever happen here. Sure, there were eccentric conspiracy theorists who saw the Pentagon's hand in the assassination of President Kennedy, ${ }^{3}$ President Nixon's downfall, ${ }^{4}$ and similar events. But even the most avid believers had to admit that no outright military takeover had ever occurred before now. Heeding Washington's admonitions in his farewell address about the dangers of overgrown military establishments, ${ }^{5}$ Americans generally viewed their armed forces with a judicious mixture of respect and wariness. ${ }^{6}$ For over two centuries that vigilance was rewarded, and most Americans came to consider the very notion of a military coup preposterous. Historian Andrew Janos captured the conventional view of the latter half of the 20th century in this clipping I saved:

A coup d'état in the United States would be too fantastic to contemplate, not only because few would actually entertain the idea, but also because the bulk of the people are strongly attached to the prevailing political system and would rise in defense of a political leader even though they might not like him. The environment most hospitable to coups d'état is one in which political apathy prevails as the dominant style. ${ }^{7}$

However, when Janos wrote that back in 1964, 61.9 percent of the electorate voted. Since then voter participation has steadily declined. By 1988 only 50.1 percent of the eligible voters cast a ballot. ${ }^{8}$ Simple extrapolation of those numbers to last spring's Referendum would have predicted almost exactly the turnout. It was precisely reversed from that of 1964: 61.9 percent of the electorate did not vote.

America's societal malaise was readily apparent in 1992. Seventy-eight percent of Americans believed the country was on the "wrong track." One researcher declared that social indicators were at their lowest level in 20 years 
and insisted "something [was] coming loose in the social infrastructure." The nation was frustrated and angry about its problems. ${ }^{9}$

America wanted solutions and democratically elected government wasn't providing them. ${ }^{10}$ The country suffered from a “deep pessimism about politicians and government after years of broken promises." ${ }^{11}$ David Finkle observed in the Washington Post Magazine that for most Americans "the perception of government is that it has evolved from something that provides democracy's framework into something that provides obstacles, from something to celebrate into something to ignore." Likewise, politicians and their proposals seemed stale and repetitive. Millions of voters gave up hope of finding answers. ${ }^{12}$ The "environment of apathy" Janos characterized as a precursor to a coup had arrived.

Unlike the rest of government the military enjoyed a remarkably steady climb in popularity throughout the 1980s and early 1990s. ${ }^{13}$ And indeed it had earned the admiration of the public. Debilitated by the Vietnam War, the US military set about reinventing itself. As early as 1988 U.S. News \& World Report heralded the result: "In contrast to the dispirited, drug-ravaged, doyour-own-thing armed services of the '70s and early ' 80 s the US military has been transformed into a fighting force of gung-ho attitude, spit-shined discipline, and ten-hut morale." ${ }^{14}$ After the US military dealt Iraq a crushing defeat in the First Gulf War, the ignominy of Vietnam evaporated.

When we graduated from the War College in 1992, the armed forces were the smartest, best educated, and best disciplined force in history. ${ }^{15}$ While polls showed that the public invariably gave Congress low marks, a February 1991 survey disclosed that "public confidence in the military soar[ed] to 85 percent, far surpassing every other institution in our society.” The armed forces had become America's most - and perhaps only — trusted arm of government. ${ }^{16}$

Assumptions about the role of the military in society also began to change. Twenty years before we graduated, the Supreme Court confidently declared in Laird v. Tatum that Americans had a "traditional and strong resistance to any military intrusion into civilian affairs." ${ }^{17}$ But Americans were now rethinking the desirability and necessity of that resistance. They compared the military's principled competence with the chicanery and ineptitude of many elected officials, and found the latter wanting. ${ }^{18}$

Commentator James Fallows expressed the new thinking in an August 1991 article in Atlantic magazine. Musing on the contributions of the military to American society, Fallows wrote: I am beginning to think that the only way the national government can do anything worthwhile is to invent a security threat and turn the job over to the military." He elaborated on his reasoning:

According to our economic and political theories, most agencies of the government have no special standing to speak about the general national welfare. Each represents a certain constituency; the interest groups fight it out. The military, strangely, is the one government institution that has been assigned legitimacy to act on its notion of the collective good. "National defense" can make us do things - train engineers, build highways - that long-term good of the nation or common sense cannot. ${ }^{19}$ 
About a decade before Fallows' article appeared, Congress initiated the use of "national defense" as a rationale to boost military participation in an activity historically the exclusive domain of civilian government: law enforcement. Congress concluded that the "rising tide of drugs being smuggled into the United States . . present[ed] a grave threat to all Americans." Finding the performance of civilian law enforcement agencies in counteracting that threat unsatisfactory, Congress passed the Military Cooperation with Civilian Law Enforcement Agencies Act of $1981 .^{20}$ In doing so Congress specifically intended to force reluctant military commanders to actively collaborate in police work. ${ }^{21}$

This was a historic change of policy. Since the passage of the Posse Comitatus Act in 1878, the military had distanced itself from law enforcement activities. ${ }^{22}$ While the 1987 law did retain certain limits on the legal authority of military personnel, its net effect was to dramatically expand military participation in anti-drug efforts. ${ }^{23}$ By 1991 the Department of Defense was spending $\$ 1.2$ billion on counternarcotics crusades. Air Force surveillance aircraft were sent to track airborne smugglers; Navy ships patrolled the Caribbean looking for drug-laden vessels; and National Guardsmen were searching for marijuana caches near the borders. ${ }^{24}$ By 1992 "combatting" drug trafficking was formally declared a "high national security mission."25

It wasn't too long before 21st-century legislators were calling for more military involvement in police work. ${ }^{26}$ Crime seemed out of control. Most disturbing, the incidence of violent crime continued to climb. ${ }^{27}$ Americans were horrified and desperate: a third even believed vigilantism could be justified. ${ }^{28}$ Rising lawlessness was seen as but another example of the civilian political leadership's inability to fulfill government's most basic duty to ensure public safety. ${ }^{29}$ People once again wanted the military to help.

Hints of an expanded police function were starting to surface while we were still at the War College. For example, District of Columbia National Guardsmen established a regular military presence in high-crime areas. ${ }^{30}$ Eventually, people became acclimated to seeing uniformed military personnel patrolling their neighborhood. ${ }^{31}$ Now troops are an adjunct to almost all police forces in the country. In many of the areas where much of our burgeoning population of elderly Americans live-Brutus calls them "National Security Zones" - the military is often the only law enforcement agency. Consequently, the military was ideally positioned in thousands of communities to support the coup.

Concern about crime was a major reason why General Brutus's actions were approved in the Referendum. Although voter participation by the general public was low, older Americans voted at a much higher rate..$^{32}$ Furthermore, with the aging of the baby boom generation, the block of American voters over 45 grew to almost 53 percent of the voters by $2010 .{ }^{33}$ This wealthy, ${ }^{34}$ older electorate welcomed an organization which could ensure their physical security. ${ }^{35}$ When it counted, they backed Brutus in the Referendum — probably the last votes they'll ever cast.

The military's constituency was larger than just the aged. Poor Americans of all ages became dependent upon the military not only for protection against crime, but also for medical care. Again we saw the roots 
of this back in 1992. First it was the barely defeated proposal to use veterans' hospitals to provide care for the non-veteran poor. ${ }^{36}$ Next were calls to deploy military medical assets to relieve hard-pressed urban hospitals. ${ }^{37}$ As the number of uninsured and underinsured grew, the pressure to provide care became inexorable. Now military hospitals serve millions of new, non-military patients. Similarly, a proposal to use so-called "underutilized" military bases as drug rehabilitation centers was implemented on a massive scale. ${ }^{38}$

Even the youngest citizens were co-opted. During the 1990s the public became aware that military officers had the math and science backgrounds desperately needed to revitalize US education. ${ }^{39}$ In fact, programs involving military personnel were already underway while we were at the War College. ${ }^{40}$ We now have an entire generation of young people who have grown up comfortable with the sight of military personnel patrolling their streets and teaching in their classrooms.

As you know, it wasn't just crises in public safety, medical care, and education that the military was tasked to mend. The military was also called upon to manage the cleanup of the nation's environmental hazards. By 1992 the armed services were deeply involved in this arena, and that involvement mushroomed. Once the military demonstrated its expertise, it wasn't long before environmental problems were declared "national security threats" and full responsibility devolved to the armed forces. ${ }^{41}$

Other problems were transformed into "national security" issues. As more commercial airlines went bankrupt and unprofitable air routes dropped, the military was called upon to provide "essential" air transport to the affected regions. In the name of national defense, the military next found itself in the sealift business. Ships purchased by the military for contingencies were leased, complete with military crews, at low rates to US exporters to help solve the trade deficit. ${ }^{42}$ The nation's crumbling infrastructure was also declared a "national security threat." As was proposed back in 1991, troops rehabilitated public housing, rebuilt bridges and roads, and constructed new government buildings. By late 1992, voices in both Congress and the military had reached a crescendo calling for military involvement across a broad spectrum of heretofore purely civilian activities. ${ }^{43}$ Soon, it became common in practically every community to see crews of soldiers working on local projects. ${ }^{44}$ Military attire drew no stares.

The revised charter for the armed forces was not confined to domestic enterprises. Overseas humanitarian and nation-building assignments proliferated. ${ }^{45}$ Though these projects have always been performed by the military on an ad hoc basis, in 1986 Congress formalized that process. It declared overseas humanitarian and civic assistance activities to be "valid military missions" and specifically authorized them by law. ${ }^{46}$ Fueled by favorable press for operations in Iraq, Bangladesh, and the Philippines during the early 1990s, humanitarian missions were touted as the military's "model for the future." ${ }^{47}$ That prediction came true. When several African governments collapsed under AIDS epidemics and famines around the turn of the century, US troops - first introduced to the continent in the 1990s - were called upon to restore basic services. They never 
left. ${ }^{48}$ Now the US military constitutes the de facto government in many of those areas. Once again, the first whisperings of such duties could be heard in $1992 .{ }^{49}$

By the year 2000 the armed forces had penetrated many vital aspects of American society. More and more military officers sought the kind of autonomy in these civilian affairs that they would expect from their military superiors in the execution of traditional combat operations. Thus began the inevitable politicization of the military. With so much responsibility for virtually everything government was expected to do, the military increasingly demanded a larger role in policymaking. but in a democracy policymaking is a task best left to those accountable to the electorate. Nonetheless, well-intentioned military officers, accustomed to the ordered, hierarchial structure of military society, became impatient with the delays and inefficiencies inherent in the democratic process. Consequently, they increasingly sought to avoid it. They convinced themselves that they could more productively serve the nation in carrying out their new assignments if they accrued to themselves unfettered power to implement their programs. They forgot Lord Acton's warning that "all power corrupts, and absolute power corrupts absolutely."50

Congress became their unwitting ally. Because of the popularity of the new military programs - and the growing dependence upon them-Congress passed the Military Plenipotentiary Act of 2005. This legislation was the legacy of the Goldwater-Nichols Defense Reorganization Act of 1986. Among many revisions, Goldwater-Nchols strengthened the office of the Chairman of the Joint Chiefs of Staff and mandated numerous changes intended to increase "jointness" in the armed services. ${ }^{51}$ Supporters of the Military Plenipotentiary Act argued that unity of command was critical to the successful management of the numerous activities now considered "military" operations. Moreover, many Congressmen mistakenly believed that Goldwater-Nichols was one of the main reasons for the military's success in the First Gulf War. ${ }^{52}$ They viewed the Military Plenipotentiary Act as an enhancement of the strengths of Goldwater-Nichols.

In passing this legislation Congress added greater authority to the military's top leadership position. Lulled by favorable experiences with Chairmen like General Colin Powell, ${ }^{53}$ Congress saw little danger in converting the office of the Chairman of the Joint Chiefs of Staff into the even more powerful Military Plenipotentiary. No longer merely an advisor, the Military Plenipotentiary became a true commander of all US services, purportedly because that status could better ameliorate the effects of perceived interservice squabbling. Despite warnings found in the legislative history of Goldwater-Nichols and elsewhere, enormous power was concentrated in the hands of a single, unelected official. ${ }^{54}$ Unfortunately, Congress presumed that principled people would always occupy the office. ${ }^{55}$ No one expected a General Brutus would arise.

The Military Plenipotentiary was not Congress's only structural change in military governance. By 2007 the services were combined to form the Unified Armed Forces. Recall that when we graduated from the War College greater unification was being seriously suggested as an economy measure. ${ }^{56}$ Eventually that consideration, and the conviction that "jointness" was an unqualified military virtue, ${ }^{57}$ led to unification. But unification ended the 
creative tension between the services. ${ }^{58}$ Besides rejecting the operational logic of separate services, ${ }^{59}$ no one seemed to recognize the checks-and-balances function that service separatism provided a democracy obliged to maintain a large, professional military establishment. The Founding Fathers knew the importance of checks and balances in controlling the agencies of government: "Ambition must be made to counteract ambition. . . . Experience has taught mankind the necessity of auxiliary controls . . . [including] supplying opposite and rival interests." 60

Ambition is a natural trait of military organizations and their leaders. ${ }^{61}$ Whatever might have been the inefficiencies of separate military services, their very existence served to counteract the untoward desires of any single service. The roles and missions debates and other arguments, once seen as petty military infighting, also provided an invaluable forum for competitive analysis of military doctrine. Additionally, they served to ensure that unscrupulous designs by a segment of the military establishment were ruthlessly exposed. Once the services were unified, the impetus to do so vanished, and the authority of the military in relation to the other institutions of government rose. ${ }^{62}$ Distended by its pervasive new duties, monolithic militarism came to dominate the Darwinian political environment of 21st-century America.

Why did the uniformed leadership of our day acquiesce to this transformation of the military? Much of the answer can be traced to the budget showdowns of the early 1990s. The collapse of the Soviet Union left the US military without an easily articulated rationale for large defense budgets. Billions in cuts were sought. Journalist Bruce Auster put it bluntly: "Winning a share of the budget wars . . . require[s] that the military find new missions for a post-Cold War world that is devoid of clear military threats."63 Capitulating, military leaders embraced formerly disdained assignments. As one commentator cynically observed, "the services are eager to talk up nontraditional, budget-justifying roles." ${ }^{4}$ The Vietnam-era aphorism, "It's a lousy war, but it's the only one we've got," was resuscitated.

Still, that doesn't completely explain why in 2012 the military leadership would succumb to a coup. To answer that question fully requires examination of what was happening to the officer corps as the military drew down in the 1980s and 1990s. Ever since large peacetime military establishments became permanent features after World War II, the great leveler of the officer corps was the constant influx of officers from the Reserve Officers Training Corps program. The product of diverse colleges and universities throughout the United States, these officers were a vital source of liberalism in the military services. ${ }^{65}$

By the late 1980s and early 1990s, however, that was changing. Force reductions decreased the number of ROTC graduates the services accepted. ${ }^{66}$ Although General Powell called ROTC “vital to democracy,” 62 ROTC programs were closed in 1991 and another 350 were considered for closure. ${ }^{67}$ The numbers of officers produced by the service academies also fell, but at a significantly slower pace. Consequently, the proportion of academy graduates in the officer corps climbed. ${ }^{68}$ Academy graduates, along with graduates of such military schools as the Citadel, Virginia Military Institute, and Norwich University, tended to feel a greater homogeneity of outlook than, say, the pool 
of ROTC graduates at large, with the result that as the proportion of such graduates grew, diversity of outlook overall diminished to some degree.

Moreover, the ROTC officers that did remain increasingly came from a narrower range of schools. Focusing on the military's policy to exclude homosexuals from service, advocates of “political correctness" succeeded in driving ROTC from the campuses of some of our best universities. ${ }^{69}$ In many instances they also prevailed in barring military recruiters from campus. ${ }^{70}$ Little thought was given the long-term consequences of limiting the pool from which our military leadership was drawn. The result was a much more uniformly oriented military elite whose outlook was progressively conservative.

Furthermore, well-meaning attempts at improving service life led to the unintended insularity of military society, representing a return to the cloistered life of the pre-World War II armed forces. Military bases, complete with schools, churches, stores, child care centers, and recreational areas, became never-to-be-left islands of tranquility removed from the chaotic, crime-ridden environment outside the gates. ${ }^{71}$ As one reporter put it in 1991: "Increasingly isolated from mainstream America, today's troops tend to view the civilian world with suspicion and sometimes hostility."72 Thus, a physically isolated and intellectually alienated officer corps was paired with an enlisted force likewise distanced from the society it was supposed to serve. In short, the military evolved into a force susceptible to manipulation by an authoritarian leader from its own select ranks.

What made this all the more disheartening was the wretched performance of our forces in the Second Gulf War. ${ }^{73}$ Consumed with ancillary and nontraditional missions, the military neglected its fundamental raison d'être. As the Supreme Court succinctly put it more than a half century ago, the "primary business of armies and navies [is] to fight or be ready to fight wars should the occasion arise." 74 When Iranian armies started pouring into the lower Gulf states in 2010, the US armed forces were ready to do anything but fight.

Preoccupation with humanitarian duties, narcotics interdiction, and all the rest of the peripheral missions left the military unfit to engage an authentic military opponent. Performing the new missions sapped resources from what most experts agree was one of the vital ingredients to victory in the First Gulf War: training. Training is, quite literally, a zero-sum game. Each moment spent performing a nontraditional mission is one unavailable for orthodox military exercises. We should have recognized the grave risk. In 1991 the Washington Post reported that in "interview after interview across the services, senior leaders and noncommissioned officers stressed that they cannot be ready to fight without frequent rehearsals of perishable skills."75

The military's anti-drug activities were a big part of the problem. Oh sure, I remember the facile claims of exponents of the military's counternarcotics involvement as to what "valuable" training it provided. ${ }^{76} \mathrm{Did}$ anyone really think that crew members of an AWACS - an aircraft designed to track high-performance military aircraft in combat-significantly improved their skills by hours of tracking slow-moving light planes? Did they seriously imagine that troops enhanced combat skills by looking for marijuana under car seats? Did they truly believe that crews of the Navy's sophisticated antiair 
and anti-submarine ships received meaningful training by following lumbering trawlers around the Caribbean? ${ }^{77}$ Tragically, they did.

The problem was exacerbated when political pressures exempted the Guard and the Reserves from the harshest effects of the budgetary cutbacks of the early 1990s. ${ }^{78}$ The First Gulf War demonstrated that modern weapons and tactics were simply too complex for part-time soldiers to master during their allotted drill periods, however well motivated. ${ }^{79}$ Still, creative Guard and Reserve defenders contrived numerous civic-action and humanitarian assignments and sold them as "training." Left unexplained was how such training was supposed to fit with the military strategies that contemplated short, violent, come-as-you-are expeditionary wars. ${ }^{80}$ Nice-to-have Guard and Reserve support-oriented programs prevailed at the expense of critical activeduty combat capabilities. ${ }^{81}$

Perhaps even more damaging than the diversion of resources was the assault on the very ethos of military service. Rather than bearing in mind the Supreme Court's admonition to focus on warfighting, the military was told to alter its purpose. Former Secretary of State James Baker typified the trendy new tone in remarks about the military's airlift of food and medicine to the former Soviet republics in early 1992. He said the airlift would "vividly show the peoples of the former Soviet Union that those that once prepared for war with them now have the courage and the conviction to use their militaries to say, 'We will wage a new peace."'82

In truth militaries ought to "prepare for war" and leave the "peace waging" to those agencies of government whose mission is just that. Nevertheless, such pronouncements — secondedbymilitaryleaders ${ }^{83}$ — became thefashionable philosophy. The result? People in the military no longer considered themselves warriors. Instead, they perceived themselves as policemen, relief workers, educators, builders, health care providers, politicians-everything but warfighters. When these philanthropists met the Iranian 10th Armored Corps near Daharan during the Second Gulf War, they were brutally slaughtered by a military which had not forgotten what militaries were supposed to do or what war is really all about.

The devastation of the military's martial spirit was exemplified by its involvement in police activities. Inexplicably, we ignored the deleterious effect on combat motivation suffered by the Israeli Defense Forces as a result of their efforts to police the West Bank and Gaza. ${ }^{84}$ Few seemed to appreciate the fundamental difference between the police profession and the profession of arms. As Richard J. Barnet observed in the New Yorker, "The line between police action and the military operation is real. Police derive their power from their acceptance as 'officers of the law'; legitimate authority, not firepower, is the essential element." 85

Police organizations are understandably oriented toward the studied restraint necessary for the end sought: a judicial conviction. As one Drug Enforcement Administration agent noted: "The military can kill people better than we can [but] when we go to a jungle lab, we're not there to move onto the target by fire and maneuver to destroy the enemy. We're there to arrest suspects and seize evidence." ${ }^{86}$ If military forces are inculcated with the same spirit 
of restraint, combat performance is threatened ${ }^{87}$ Moreover, law enforcement is also not just a form of low-intensity conflict. In low-intensity conflict, the military aim is to win the will of the people, a virtually impossible task with criminals "motivated by money, not ideology." 88

Humanitarian missions likewise undermined the military's sense of itself. As one Navy officer gushed during the 1991 Bangladesh relief operation, "It's great to be here doing the opposite of a soldier." ${ }^{99}$ While no true soldier relishes war, the fact remains that the essence of the military is warfighting and preparation for the same. What journalist Barton Gellman has said of the Army can be extrapolated to the military as a whole: it is an "organization whose fighting spirit depends . . . heavily on tradition." 90 If that tradition becomes imbued with a preference for "doing the opposite of a soldier," fighting spirit is bound to suffer. When we first heard editorial calls to "pacify the military" by involving it in civic projects, ${ }^{91}$ we should have given them the forceful rebuke they deserved.

Military analyst Harry Summers warned back in '91 that when militaries lose sight of their purpose, catastrophe results. Citing a study of pre-World War II Canadian military policy as it related to the subsequent battlefield disasters, he observed that:

instead of using the peacetime interregnum to hone their military skills, senior Canadian military officers sought out civilian missions to justify their existence. When war came they were woefully unprepared. Instead of protecting their soldiers' lives they led them to their deaths. In today's post-Cold War peacetime environment, this trap again looms large. . . . Some today within the US military are also searching for relevance, with draft doctrinal manuals giving touchy-freely prewar and postwar civil operations equal weight with warfighting. This is an insidious mistake..$^{92}$

We must remember that America's position at the end of the Cold War had no historical precedent. For the first time the nation - in peacetime - found itself with a still-sizable, professional military establishment that was not preoccupied with an overarching external threat. ${ }^{93}$ Yet the uncertainties in the aftermath of the Cold War limited the extent to which those forces could be safely downsized. When the military was then obliged to engage in a bewildering array of nontraditional duties to further justify its existence, it is little wonder that its traditional apolitical professionalism eventually eroded.

Clearly, the curious tapestry of military authoritarianism and combat ineffectiveness that we see today was not yet woven in 1992. But the threads were there. Knowing what I know now, here's the advice I would have given the War College Class of 1992 had I been their graduation speaker:

- Demand that the armed forces focus exclusively on indisputably military duties. We must not diffuse our energies away from our fundamental responsibility for warfighting. To send ill-trained troops into combat makes us accomplices to murder.

- Acknowledge that national security does have economic, social, educational, and environmental dimensions, but insist that this doesn't necessarily mean the problems in those areas are the responsibility of the military to 
correct. Stylishly designating efforts to solve national ills as "wars" doesn't convert them into something appropriate for the employment of military forces.

- Readily cede budgetary resources to those agencies whose business it is to address the non-military issues the armed forces are presently asked to fix. We are not the DEA, EPA, Peace Corps, Department of Education, or Red Crossnor should we be. It has never been easy to give up resources, but in the long term we-and the nation — will be better served by a smaller but appropriately focused military.

- Divest the defense budget of perception-skewing expenses. Narcotics interdiction, environmental cleanup, humanitarian relief, and other costs tangential to actual combat capability should be assigned to the budgets of DEA, EPA, State, and so forth. As long as these expensive programs are hidden in the defense budget, the taxpayer understandably—but mistakenly—will continue to believe he's buying military readiness.

- Continue to press for the elimination of superfluous, resource-draining Guard and Reserve units. Increase the training tempo, responsibilities, and compensation of those that remain.

- Educate the public to the sophisticated training requirements occasioned by the complexities of modern warfare. It's imperative we rid the public of the misperception that soldiers in peacetime are essentially unemployed and therefore free to assume new missions. ${ }^{94}$

- Resist unification of the services not only on operational grounds, but also because unification would be inimical to the checks and balances that underpin democratic government. Slow the pace of fiscally driven consolidation so that the impact on less quantifiable aspects of military effectiveness can be scrutinized.

- Assure that officer accessions from the service academies correspond with overall force reductions (but maintain separate service academies) and keep ROTC on a wide diversity of campuses. If necessary, resort to litigation to maintain ROTC campus diversity.

- Orient recruiting resources and campaigns toward ensuring that all echelons of society are represented in the military, without compromising standards. ${ }^{95}$ Accept that this kind of recruiting may increase costs. It's worth it.

- Work to moderate the base-as-an-island syndrome by providing improved incentives for military members and families to assimilate into civilian communities. Within the information programs for our force of all-volunteer professionals (increasingly US-based), strengthen the emphasis upon such themes as the inviolability of the Constitution, ascendancy of our civilian leadership over the military, and citizens' responsibilities.

Finally, I would tell our classmates that democracy is a fragile institution that must be continuously nurtured and scrupulously protected. I would also tell them that they must speak out when they see the institution threatened; indeed, it is their duty to do so. Richard Gabriel aptly observed in his took To Serve with Honor that:

when one discusses dissent, loyalty, and the limits of military obligations, the central problem is that the military represents a threat to civil order not because it will usurp authority, but because it does not 
speak out on critical policy decisions. The soldier fails to live up to his oath to serve the country if he does not speak out when he sees his civilian or military superiors executing policies he feels to be wrong. ${ }^{96}$

Gabriel was wrong when he dismissed the military's potential to threaten civil order, but he was right when he described our responsibilities. The catastrophe that occurred on our watch took place because we failed to speak out against policies we knew were wrong. It's too late for me to do any more. But it's not for you.

Best regards,

Prisoner 222305759

\section{Notes}

1. The Twenty-Fifth Amendment to the Constitution provides that in the case of "death ... the Vice President shall become the President.” But Section 1 of Article II requires the taking of the oath before "enter[ing] the Execution of his Office."

2. Daniel J. Boorstin, "History's Hidden Turning Points," U.S. News \& World Report, 22 April 1991, p. 52.

3. Oliver Stone's movie, JFK, is one example. See Joel Achenback, "JFK Conspiracy: Myth vs. Facts,” The Washington Post, 28 February 1992, p. C5.

4. See Len Colodny and Robert Gettlin, Silent Coup (New York: St. Martin's, 1991).

5. George Washington in his "Farewell Address" dated 19 September 1796 counseled: "Overgrown military establishments . . . under any form of government are inauspicious to liberty and ... are to be regarded as particularly hostile to republican liberty." As quoted in The Annals of America (Chicago: Encyclopedia Britannica, 1976), p. 609.

6. Author Geoffrey Perret expressed the traditional view as follows: "The antimilitaristic side of the American character is forever on guard. Americans are so suspicious of military ambition that even when the armed forces win wars they are criticized as robustly as if they had lost them." $A$ Country Made By War (New York: Vintage, 1989), p. 560.

7. Andrew C. Janos, "The Seizure of Power: A Study of Force and Popular Consent," Research Monograph No. 16, Center for International Studies, Princeton University, 1964, p. 39.

8. Mark S. Hoffman, ed., The World Almanac \& Book of Facts 1991 (New York: Pharo Books, 1990), p. 426: Royce Crocker, Voter Registration and Turnout 1948-1988, Library of Congress, Congressional Research Services Report No. 89-179 (Washington: LOC, 1989), p. 11.

9. E. J. Dionne, Jr., "Altered States: The Union \& the Campaign," The Washington Post, 26 January 1992, p. C1. Fordham University researcher Marc Miringoff reports that the Index of Social Indicators fell to its lowest point in 20 years. He describes the Index, which is an amalgamation of social economic data from government sources, as "sort of a Dow Jones of the national soul." See Paul Taylor, "'Dow Jones of the National Soul' Sours," The Washington Post, 16 January 1992, p. A25. The nation's frustration was the cause, according to columnist George F. Will, of a rising level of collective "national stress." George F. Will, "Stressed Out in America," The Washington Post, 16 January 1992, p. A27. See also Charles Krauthammer, "America's Case of the Sulks," The Washington Post, 16 January 1992, p. C7.

10. A 1989 Harris poll revealed that $53 \%$ of Americans believed that Congress was not effectively fulfilling its responsibilities. See Robert R. Ivany, "Soldiers and Legislators: Common Mission," Parameters, 21 (Spring 1991), 47.

11. Mortimer B. Zuckerman, "Behind Our Loss of Faith," U.S. News \& World Report, 16 March 1992 , p. 76. Many believed that democracy's promise didn't include them. Ninety-one percent of Americans reported that the "group with too little influence in government is people like themselves." See "Harper's Index," Harper's Magazine, January 1991, p. 17.

12. David Finkle, 'The Greatest Democracy on Earth,” The Washington Post Magazine, 16 February 1992, p. 16. Forty-three percent of those who failed to vote didn't see any important differences between the two major parties. See "Harper's Index," Harper's Magazine, March 1992, p. 13. One in eight Americans was so pessimistic as to conclude that the country's domestic problems were "beyond solving." "Harper’s Index," Harper's Magazine, October 1991, p. 15.

13. A ten-year rise in public confidence was reported by Tom Morganthau, et al., in "The Military's New Image," Newsweek, 11 March 1991, p. 50.

14. Michael Satchell, et al., "The Military's New Stars," U.S. News \& World Report, 18 April 1988, p. 33. 
15. A survey of 163 new Army brigadier generals revealed that their IQ was in the 92nd percentile of the population. See Bruce W. Nelan, "Revolution in Defense," Time, 18 March 1991, p. 25. In many instances the curricula vitae of military personnel was more impressive than that of their civilian counterparts. For example, over $88 \%$ of brigadier generals had an advanced degree compare with $19 \%$ of top civilian business leaders. See David Gergen, "America's New Heroes," U.S. News \& World Report, 11 February 1991, p. 76. Similarly, 97\% of enlisted personnel were high school graduates, the highest percentage ever. See Grant Willis, "DoD: Recruits in '91 Best Educated, Most Qualified," Air Force Times, 27 January 1992, p. 14. The services "had become practically a drug-free workplace." See Daivd Gergen, "Bringing Home the Storm," The Washington Post, 28 April 1991, p. C2. Military sociologist Charles Moskos explained that the reason for the great decline in disciplinary problems is "simply better recruits." Peter Slavin, "Telling It Like It Is," Air Force Times, 14 March 1988, p. 60.

16. Ivany, 47; David Gergen, “America's New Heroes,” p. 76; Grant Willis, “A New Generation of Warriors," Navy Times, 16 March 1991, p. 12.

17. 408 U.S. 1,17 (1972).

18. At least one observer sensed the peril which arises when power and respect converge in the military: "Our warriors are kinder and gentler, and have not shown the slightest inclination to lust for political power. But that potential always lurks where power and respect converge, and the degree of military influence in society is something to watch carefully in the years ahead." Martin Anderson, "The Benefits of the Warrior Class," The Baltimore Sun, 14 April 1991, p. 3F.

19. James Fallows, "Military Efficiency," Atlantic, August 1991, p. 18.

20. Civilian law enforcement agencies were intercepting only $15 \%$ of the drugs entering the country. See U.S. Code Congressional \& Administrative News (St. Paul: West, 1981), p. 1785; Public Law 97-86 (1981) codified in 10 U.S.C. 371 et seq.

21. Newsweek reports: "The Pentagon resisted the [counternarcotics] mission for decades, saying that the military should fight threats to national security, and the police should fight crime." Charles Lane, "The Newest War," Newsweek, 6 January 1992, p. 18. See also U.S. Code Congressional \& Administrative News (St. Paul: West, 1981), p. 1785.

22. The original purpose of the Posse Comitatus Act (10 U.S.C. 1385) was to restrain Federal troops who had become deeply involved in law enforcement in the post-Civil War South-even in areas were civil government had been reestablished. See U.S. v. Hartley, 486 F. Supp. 1348, 1356 fn. 11 (M.D. Fla. 1980). The statute imposes criminal penalties for the improper uses of the military in domestic law enforcement matters. See U.S. Code Congressional \& Administrative News (St. Paul: West, 1981), p. 1786.

23. Additional amendments were added in 1988. See Public Law 100-456 (1988).

24. Although anti-drug spending will decrease in FY 93, the rate of decline is slower than that of the DOD budget as a whole, William Matthews, "Counternarcotics Request Increased," Air Force Times, 24 February 1992, p. 2. See also Lane, "Newest War,” p. 18.

25. "Combating Drugs," National Military Strategy of the United States (Washington: GPO, 1992), p. 15.

26. Some were suggesting the need for greater military authority in 1992. See Dale E. Brown, "Drugs on the Border: The Role of the Military," Parameters, 21 (Winter 1991-92), 58-59.

27. The rise in the rate of violent crime continued a trend begun in the 1980s when such offenses soared by $23 \%$. See John W. Wright, ed., "Crime and Punishment," The Universal Almanac 1992 (Kansas City: Andrews and McMeel, 1991), p. 255.

28. "Harper's Index," Harper's Magazine, July 1991, p. 15.

29. George Will observed that "urban governments are failing to perform their primary function of protecting people from violence on streets and even in homes and schools." George F. Will, "Stressed Out in America," p. A27.

30. Using Guardsmen in a law enforcement capacity during riots and other emergencies was not unusual, but a regular presence in a civilian community in that role was unusual in those days. Guard members usually performed law enforcement activities in their status as state employees. This is distinct from their federalized status when they are incorporated into the US military. See U.S. Code Congressional \& Administrative News (St. Paul: West, 1988), p. 2583; and K. R. Clark, "Spotlighting the Drug Zones," Pentagram, 30 January 1992, pp. 20-21.

31. Indeed, one of the specific purposes of the DC program was to "work with police to increase the uniformed presence in the neighborhood at night to cut down on illegal activity," See Clark p. 21.

32. For example, persons over the age of 65 vote at a rate $50 \%$ higher than that of the 18-34 age group. See George F. Will, "Stressed Out in America," p. A27.

33. The number of baby boomers in the population is expected to peak in 2020. See Marvin J. Cetron and Owen Davies, “Trends Shaping the World,” The Futurist, September-October 1991, p. 12. Persons over 65 were estimated to constitute $18 \%$ of the electorate by 2010 . This group, together with the boomers over 45 years, would constitute $53 \%$ of the electorate by 2010 . These percentages were 
computed from statistics found in the Universal Almanac 1992, "The U.S. Population Age," John W. Wright, ed. (Kansas City: Andrews and McMeel, 1991), p. 207.

34. Deidre Fanning, "Waiting for the Wealth," Worth, February/March 1992, pp. 87, 89.

35. A 1990 poll of Americans aged 50 years and older showed that nearly $23 \%$ believed that use of the military was the best way to combat the growing problems of drug abuse and crime. See Mark S. Hoffman, ed., The World Almanac \& Book of Facts 1991 (New York: Pharo Books, 1990), p. 33.

36. "Plan to Open Veterans Hospitals to Poor is Dropped," The New York Times, 23 February 1992, p. 17.

37. Scott Shuger, "Pacify the Military," The New York Times, 14 March 1992, p. 25.

38. Andy Tobias, "Let's Get Moving!" Time, 3 February 1992, p. 41.

39. U.S. News \& World Report noted that "a third of the officers leaving the Army are qualified to teach high school math, and 10 to 20 percent can teach physics." David Gergen, "Heroes For Hire," U.S. News \& World Report, 27 January 1992, p. 71.

40. For example, a District of Columbia National Guard unit entered into a "Partnership in Education" agreement with a local school district. Under the memorandum the Guard agreed to "institute a cooperative learning center providing tutoring in science, English, mathematics, and other basic subjects." See "Guard Enters Partnership with School," Pentagram, 13 February 1992, p. 3. For another example, see "Arlington Schools Join Forces with Defense Department Agency," The Washington Post, 12 December 1991, p. Va1.

41. The DOD budget for environmental cleanup for FY 93 was $\$ 3.7$ billion. Anne Garfinkle, "Going Home is Hard to Do," The Wall Street Journal, 27 January 1992, p. 12. See also Peter Grier, "US Defense Department Declares War on Colossal Pollution Problem," The Christian Science Monitor, 2 March 1992, p. 9. The Army, at least, saw this activity as a "vital mission" as early as 1991. The National Journal reported: "Outside the Storm, a pamphlet heralding the Army's post-Persian Gulf war 'vital missions and important work' touches on the war on drugs and 'protecting the planet earth' (even reprinting a syrupy ode to environmentalism from the 1989 Sierra Club Wilderness Calendar)." David C. Morrison, "Operation Kinder and Gentler," National Journal, 25 May 1991, p. 1260.

42. In February 1992 Trans World Airlines became the eighth major airline to go bankrupt since 1989. Martha M. Hamilton, "Trans World Airlines Files for Bankruptcy," The Washington Post, 1 February 1992, p. C2. By 1992 US-flagged commercial shipping had virtually disappeared. See James Bovard, "The Antiquated 1920 Jones Act Slowly Sinks U.S. Shipping," Insight, 6 January 1992, p. 21. In the wake of Desert Storm, $\$ 3.1$ billion was spent to build and convert ships for the military's cargo fleet. Michael Blood, "An Idea to Use Shipyard as a U.S. Sealift Base," Philadelphia Inquirer, 16 February 1992, p. B-1. The precedent for "leasing" military resources can be traced to 1992. Just such an arrangement occurred in Germany following reunification: "A shortage of German [air] controllers and their unfamiliarity with newly reunified Berlin's busy skies prompted Germany to hire a squadron from the US Air Force at a cost of $\$ 35$ million for four years. . . . It is the only US military unit that guides civilian air traffic on foreign soil." Soraya S. Nelson, "AF Controllers in Berlin Keep Eye on Civilian Sky," Air Force Times, 10 February 1992, p. 22.

43. See, e.g., Helen Dewar, "Nunn Urges Military Shift: Forces Would Aid Domestic Programs," The Washington Post, 24 June 1992, p. A17; Rick Maze, "Nunn Urges Military to Take Domestic Missions, Army Times, 21 September 1992, p. 16; Mary Jordan, "Bush Order U.S. Military to Aid Florida," The Washington Post, 28 August 1992, p. A1; George C. Wilson, "Disaster Plan: Give Military the Relief Role," Army Times, 21 September 1992, p. 22; and Rick Maze, "Pentagon May Get Disaster-relief Role Back," Army Times, 21 September 1992, p. 26. See also note 64.

44. See Shuger, p. 25. Similarly, noting the growing obsolescence of the Guard's combat role, a National Guard officer proposed an alternative: "The National Guard can provide a much greater service to the nation by seeking more combat support and combat service support missions and the structure to support them. Such units can participate in nation building or assistance missions throughout the world, to include the United States. . . . Much of our national infrastructure, streets, bridges, health care, water and sewer lines, to name just a few, particularly in the inner cities of the United States, are in disrepair. Many of the necessary repairs could be accomplished by National Guard units on a year-round training basis." Colonel Philip Drew, "Taking the National Guard Out of Combat," National Guard, April 1991, p. 38. Also jumping on the bandwagon are National Guard officers Colonel Philip A. Brehm and Major Wilbur E. Gray in "Alternative Missions for the Army," SSI Study, Strategic Studies Institute, USAWC, 17 July 1992.

45. Eric Schmidt, "U.S. Forces Find Work As Angels of Mercy," The New York Times, 12 January 1992, p. E3.

46. See the legislative history of Public Law 99-661, U.S. Code Congressional \& Administrative News (St. Paul: West, 1986) p. 6482. Public Law 99-661 codified in 10 U.S.C. 401 et seq. 
47. Ken Adleman, “Military Helping Hands,” Washington Times, 8 July 1991, p. D3; Bruce B. Auster with Robin Knight, "The Pentagon Scramble to Stay Relevant," U.S. News \& World Report, 30 December 1991/6 January 1992, p. 52.

48. It was predicted that the AIDS epidemic would hit Africa especially hard with infection rates in some cities as high as $40 \%$ by the year 2000. See Marvin J. Cetron and Owen Davies, "Trends Shaping the World," The Futurist, September-October 1991, p. 12. Some experts have predicted that African famine might present a requirement for a military humanitarian mission (Weiss and Campbell, pp. 451-52). See also Richard H. P. Sia, "U.S. Increasing Its Special Forces Activity in Africa," The Baltimore Sun, 15 March 1992, p. 1. Long-term military commitments to humanitarian operations have been recommended by some experts (Weiss and Campbell, p. 457).

49. US troops assigned to African countries in the early 1990s were tasked to "help improve local health-care and economic conditions." See Sia, p. 1. Similarly, the notion of using the expertise of US military personnel to perform governmental functions in foreign countries was also suggested in the 1990s. For example, when the food distribution system in the former Soviet Union broke down during the winter of 1991-92, there were calls for Lieutenant General Gus Pagonis, the logistical wizard of the First Gulf War, to be dispatched to take charge of the system. See "A Man Who Knows How," editorial, The Los Angeles Times, 5 February 1992, p. 10.

50. As quoted in Dictionary of Military and Naval Quotation, Robert Debs Heinl, Jr., ed. (Annapolis: US Naval Institute, 1966), p. 245.

51. Public Law 99-433 (1986). Under the Goldwater-Nichols Defense Reorganization Act, the Chairman of the JCS was given much broader powers. Not only is he now the primary military advisor to the President, he is also responsible for furnishing strategic direction to the armed forces, strategic and contingency planning, establishing budget priorities, and developing joint doctrine for all four services. Edward Luttwak and Stuart L. Koehl, eds., The Dictionary of Modern War (New York: Harper Collins, 1991), p. 320. The law also mandated that joint duty be a requirement for promotion to flag rank. See Vincent Davis, "Defense Reorganization and National Security," The Annals of the American Academy of Political Science, September 1991, pp. 163-65. This facilitated development of senior military cliques which transcended service lines.

52. Many praised Goldwater-Nichols as the source of success in the Gulf War. See, e.g., "Persian Gulf War's Unsung Hero," editorial, Charleston, S.C., News \& Courier, 4 April 1991, p. 6. See also Sam Nunn, "Military Reform Paved Way for Gulf Triumph," Atlanta Constitution, 31 March 1991, p. G5. But the Gulf War was not a true test of either Goldwater-Nichols or joint warfare. About all that conflict demonstrated was that poorly trained and miserably led conscript armies left unprotected from air attack cannot hold terrain in the face of a modern ground assault.

53. One study concluded that because of Powell's background he was "especially well qualified" for the politically sensitive role as CJCS. See Preston Niblock, ed., Managing Military Operations in Crises (Santa Monica: RAND, 1991), p. 51.

54. Representative Denton stated as to Goldwater-Nichols: "This legislation proposes to reverse 200 years of American history by, for the first time, designating by statute . . . a single uniformed officer as the 'Principal Military Advisor' to the President. That change in the role of the Chairman of the Joint Chiefs of Staff is profound in its implications. Similar proposals have been specifically and overwhelmingly rejected in the past —in 1947, 1949, 1958 — on the grounds that, in a democracy, no single military officer, no matter what his personal qualification, should have such power." U.S. Code Congressional \& Administrative News (St. Paul, Minn.: West, 1986), p. 2248. See also Robert Previdi, Civilian Control versus Military Rule (New York: Hippocrene Books, 1988).

55. In The Federalist No. 51 the Founding Fathers warned against the folly of constructing a governmental system based on assumptions about the good character of individuals who might occupy an office.

56. William Matthews, "Nunn: Merge the Services?” Air Force Times, 9 March 1992, p. 6.

57. This belief was enshrined in Joint Pub 1, Joint Warfare of the United States (Washington: Office of the JCS, 11 November 1991). It states (p. iii) that "joint warfare is essential to victory." While joint warfare might usually be essential to victory, it cannot be said that it is essential in every instance. For example, rebels - composed entirely of irregular infantry-defeated massive Soviet combined-arms forces in Afghanistan. Equipped only with light arms, Stinger missiles, and light antiaircraft guns, they triumphed without benefit of any air or naval forces, and indeed without unity among themselves. Furthermore, even in the case of Western nations, there are likely to be plenty of hostilities involving single-service air or naval campaigns.

58. Former Secretary of the Navy John Lehman described the value of this creative tension in discussing his criticism of the "unified" Chairman of the Join Chiefs of Staff occasioned by Goldwater-Nichols. According to Lehman: "Franklin Roosevelt . . . wanted to hear Admiral King argue with Marshall in front of him. He wanted to hear MacArthur argue against Nimitz, and the Air Corps against the Army, and the Navy against all in his presence, so that he would have the option to make the decisions of major strategy in war. He knew that any political leader, no matter how strong, 
if given only one military position, finds it nearly impossible to go against it. Unfortunately . . now the president does not get to hear arguments from differing points of view." John Lehman, "U.S. Defense Policy Options: The 1990s and Beyond," The Annals of the American Academy of Political and Social Science, September 1991, pp. 199-200.

59. See, e.g., Arthur C. Forster, Jr., "The Essential Need for An Independent Air Force," Air Force Times, 7 May 1990, p. 25.

60. Alexander Hamilton, James Madison, and John Jay, The Federalist, as reprinted in the Great Books of the Western World, Robert M Hutchins, ed. (Chicago: Encyclopedia Britannica, 1952), XLIII, 163.

61. Shakespeare called ambition "the soldier's virtue.” Antony and Cleopatra, Act III, Scene 1, as reprinted in Great Books of the Western World, Robert M. Hutchins, ed. (Chicago: Encyclopedia Britannica, 1952), XXVII, 327.

62. Samuel P. Huntington, The Soldier and the State (Cambridge: Harvard Univ. Press, 1959), p. 87 , said "If the officer corps is originally divided into land, sea, and air elements, and then is unified under the leadership of a single, overall staff and military commander in chief, this change will tend to increase its authority with regard to other institutions of government. It will speak with one voice instead of three. Other groups will not be able to play off one of the officer corps against another."

63. Bruce B. Auster with Robin Knight, “The Pentagon Scramble to Stay Relevant,” U.S. News \& World Report, 30 December 1991/6 January 1992, p. 52. Despite the Gulf War, defense outlays were scheduled by 1997 to shrink to their lowest percentage of the federal budget since the end of World War II. Sara Collins, "Cutting up the Military," U.S. News \& World Report, 10 February 1992, p. 29. See also John Lancaster, "Aspin Seeks to Double Bush's Defense Cuts," The Washington Post, 27 February 1992, p. A16; and Helen Dewar, "Bush, Mitchell Take Aim at Slashing the Defense Budget,” The Washington Post, 17 January 1992, p. B1.

64. Morrison, "Operation Kinder and Gentler," p. 1260. Most revealing, on 1-2 December 1992, the National Defense University at Fort McNair in Washington D.C., hosted a symposium titled "Non-Traditional Roles for the U.S. Military in the Post-Cold War Era," featuring presentations on disaster relief, refugee evacuation, humanitarian medical care, engineering assistance to infrastructure and environment, counternarcotics, riot control, emergency preparedness, civil unrest, national assistance, etc.

65. Military analyst Harry Summers insists that ROTC is a key reason military coups have not occurred in the United States as they have in other countries. He notes: "ROTC was designed to produce a well-rounded officer corps inculcated with the principles of freedom, democracy, and American values through close contact with civilian students on an open college campus, and through a liberal education taught by a primarily civilian academic faculty. And that's just what has happened." Harry Summers, "Stalking the Wrong Quarry," Washington Times, 7 December 1989, p. F-3.

66. The Army plans to cut ROTC officer acquisitions from 7,778 in 1990 to 5,200 in 1995. See Peter Copeland, "ROTC More Selective in Post-Cold War Era," Washington Times, 27 May 1991, p. 3.

67. David Wood, “A Breed Apart, Volunteer Army Grows Distant from Society,” The Star Ledger (Newark, N.J.), 24 April 1991, p. 1.

68. The armed services will shrink at least $25 \%$ by 1995 , Richard Cheney, "U.S. Defense Strategy for An Era of Uncertainty," International Defense Review, 1992, p. 7. But service academy graduates are expected to decline by only $10 \%$ during the same period. Eric Schmitt, "Service Academies Grapple With Cold War Thaw," The New York Times, 3 March 1992, p. 12. Just after the Vietnam War, West Point was supplying about 8\% of new Army officers, compared to the current $24 \%$, a new study by the congressional General Accounting Office (GAO) suggests. To roll back the officer stream from West Point, the GAO says, enrollment might have to be limited to 2,500 cadets, a 40\% drop from today. Larry Gordon, "Changing Cadence at West Point," Los Angeles Times, 25 March 1992, p. 1.

69. See, e.g., Tom Philip, “CSUS May End ROTC Over Anti-Gay Policy,” Sacramento Bee, 15 February 1992, p. 1.

70. As of November 1991, 89 law schools prohibit or restrict on-campus military recruiting. See “Sexual Preference Issue,” HQ USAF/JAX Professional Development Update, November 1991, p. 9. Such bans are not legal in most cases of military recruiters from campuses-billed as "marketplaces of ideas”-these universities legitimized censorship of "politically incorrect” views.

71. An article by journalist David Wood grasped this trend. He quoted an Army officer as stating, “We are isolated—we don't have a lot of exposure to the outside world." Wood goes on to observe: "The nation's 2 million active duty soldiers are a self-contained society, one with its own solemn rituals, its own language, its own system of justice, and even its own system of keeping time. ... Only a decade ago, life within the confines of a military base might have seemed a spartan existence. But improving the garrison life has been a high priority. As a result, many bases have come to resemble an ideal of small-town America. . . . There is virtually no crime or poverty. Drug addicts and home- 
less are mere rumors from the outside." David Wood, "Duty, Honor, Isolation: Military More and More a Force Unto Itself." The Star-Ledger (Newark, N.J.) 21 April 1991, p. 1. See also Laura Elliot, "Behind the Lines," The Washingtonian, April 1991, p. 160.

72. Wood, p. 1.

73. Studies indicate that defeat in war may actually increase the likelihood of a military coup. Ekkart Zimmermann, "Toward a Causal Model of Military Coups d'Etat," Armed Forces and Society, 5 (Spring 1979), 399.

74. United States ex rel. Toth v. Quarles, 350 U.S. 11, 17, 76 S.Ct. 1 (1955). Of course, Carl von Clausewitz had put it even better: "The end for which a soldier is recruited, clothed, armed, and trained, the whole object of his sleeping, eating, drinking, and marching, is simply that he should fight at the right place and the right time." On War, Michael Howard and Peter Paret, eds. (Princeton Univ. Press, 1976), p. 95.

75. Barton Gellman, “Strategy for the '90s: Reduce Size and Preserve Strength,” The Washington Post, 9 December 1991, p. A10.

76. See, e.g., Brown, "Drugs on the Border: The Role of the Military," p. 50.

77. According to one report, the effort was futile and wasteful: "We're getting so little of the drug traffic for such a great expenditure of effort," lamented one Navy officer, "We're pouring money into the ocean, at a time when resources are scarce." William Matthews, "Drug War Funds Would Shrink Under Budget Proposal," Air Force Times, 17 February 1992, p. 33.

78. John Lancaster reported that proposals to cut Guard and Reserve funding "inflame passions on Capitol Hill," causing Congress to resist cutting the part-time forces. "Pentagon Cuts Hill-Favored Targets,” The Washington Post, 24 January 1992, p. A6. Art Pine reported that the Guard and Reserves "exercise stunning political power and influences, both among state and local governments and in the power center of Washington." Pine quoted Brookings Institute expert Martin Binkin as saying that the Guard/Reserve lobby "makes the gun lobby led by the National Rifle Association look like amateurs.” Art Pine, “In Defense of 2nd Line Defenders,” Los Angeles Times, 13 March 1992, p. 1.

79. Former Director of Operations for the Joint Staff, Lieutenant General Thomas Kelly, believed there was simply not enough training time to keep Guard units ready for the kind of highly complex warfare the Army now conducts. He said, "There is nothing on earth harder to teach than the maneuver function in combat.” As quoted by Grant Willis, “A New Generation of Warriors," Navy Times, 16 March 1991, p. 12. The motivation of some Guardsmen toward fulfilling their military responsibilities was called into question when up to $80 \%$ of the Guardsmen in California units called up for the Desert Storm reported for duty unable to meet physical fitness standards. Steve Gibson, "Guards Flunked Fitness,” Sacramento Bee, 18 June 1991, p. B1.

80. “Decisive Force,” National Military Strategy of the United States (Washington: GPO, 1992), p. 10; “Contingency Forces," National Military Strategy of the United States (Washington: GPO, 1992), p. 23. Secretary of Defense Richard Cheney and Chairman of the Joint Chiefs of Staff Colin Powell testified before the Senate Armed Services Committee on 31 January 1992 that the military of the future "would be smaller and more mobile and flexible. . . . Its likely target would be regional conflicts, in which American firepower might still be needed on short notice." As reported by Eric Schmitt, "Pentagon Says More Budget Cuts Would Hurt Combat Effectiveness," The New York Times, 1 February 1992, p. 9.

81. Military analyst and decorated combat veteran David Hackworth sized up the Guard and Reserves as follows: “Except for the air and Marine combat components, these forces aren't worth the billions paid each year to them. The combat service and support units are great, but there are too many of them.” “A Pentagon Dreamland,” The Washington Post, 23 February 1992, p. C3.

82. Operation Provide Hope was a two-week humanitarian aid effort involving 64 US Air Force sorties carrying approximately 4.5 million pounds of food and medicine. Michael Smith, "First of Up to 64 Relief Flights Arrives in Kiev," Air Force Times, 24 February 1992, p. 8. For Baker quotation, see David Hoffman, "Pentagon Airlift Aid to Republic," The Washington Post, 24 January 1992, p. A1.

83. The Vice Chairman of the Joint Chiefs of Staff also saw the military's future role in noncombat terms. Stating that there was "no plausible scenario" in which the United States would be involved in a military conflict in Europe or with elements of the former Soviet Union, he maintained that the likeliest use of military forces would be to address instability that could arise from migrations by poor peoples of the world to wealthier regions. He envisioned the military's role: "You would like to deal with this on a political and social level. The military's role should be subtle, similar to the role it plays now in Latin America-digging wells, building roads, and teaching the militaries of host nations how to operate under a democratic system. . . . When prevention fails, the military can be called to the more active role of running relief operations like the current one at Guantanamo Bay, Cuba, for fleeing Haitians. Operation Provide Comfort, the giant US military rescue mission to save Kurdish refugees who fled from the Iraqi army to the snow-covered mountains of southeastern Turkey last spring, may have been a precursor of what we can look forward to in the next decade if 
not the next century." As quoted by William Matthews, "Military Muscle to Shift to Humanitarian Help," Air Force Times, 6 January 1992, p. 14.

84. Leon Hader, "Reforming Israel-Before It's Too Late," Foreign Policy, No. 81 (Winter 1990/91, 111.

85. Richard J. Barnet, "Reflections_-The Uses Of Force,” The New Yorker, 29 April 1991, p. 82.

86. Charles Lane, “The Newest War,” p. 18.

87. Newsweek reported the following incident: When a Marine reconnaissance patrol skirmished with smugglers near the Arizona-Mexico border last December-firing over their heads to disperse them-one colonel near retirement age shook his head. He argued that combat-trained Marines shouldn't be diminishing hard-learned skills by squeezing off warming shots. "That teaches very bad habits," he said. Bill Torque and Douglas Waller, "Warriors Without War,” Newsweek, 19 March 1990, p. 18.

88. Charles Lane, “The Newest War,” p. 18.

89. As quoted by David Morrison in the National Journal. This relief operation involved 8,000 sailors and marines tasked to help millions of Bangladeshi survivors of a 30 April 1991 cyclone. See Morrison, "Operation Kinder and Gentler," p. 1260.

90. Barton Gellman, “Strategy for the '90s: Reduce Size and Preserve Strength,” The Washington Post, 9 December 1991, p. A10.

91. Shuger, "Pacify the Military," p. 25.

92. Harry Summers, "When Armies Lose Sight of Purpose," Washington Times, 26 December 1991, p. D3.

93. See "Warnings Echo from Jefferson to Eisenhower to Desert Storm," USA Today, 1 March 1991, p. 10A.

94. A caller to a radio talk show typified this view. She stated that while she appreciated the need for a military in case "something like Iraq came up again," she believed that the military ought to be put to work rebuilding the infrastructure and cleaning up the cities instead of "sitting around the barracks." "The Joel Spevak Show," Station WRC, Washington, D.C., 11 March 1992.

95. One example of the dangers of lowering standards to achieve social goals is "Project 100,000." Conceived as a Great Society program, youths with test scores considered unacceptably low were nevertheless allowed to enter the armed forces during the 1966-1972 period. The idea was to give the disadvantaged poor the chance to obtain education and discipline in a military environment, but the results were a fiasco. See Marilyn B. Young, The Vietnam Wars, 1945-1990 (New York: Harper Collins, 1991), p. 320.

96. Richard A. Gabriel, To Serve with Honor (Westport, Conn.: Greenwood, 1982), p. 178. 